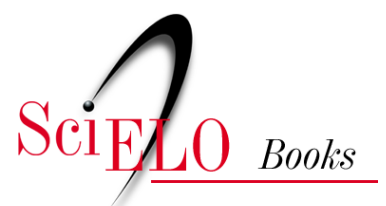

\title{
Capítulo 2. Cidades novas e a necessidade
}

\author{
Ricardo Trevisan
}

\section{SciELO Books / SciELO Livros / SciELO Libros}

TREVISA, R. Cidades novas e a necessidade. In: Cidades novas [online]. Brasília: Editora UnB, 2020, pp. 129-149. Pesquisa, inovação \& ousadia series. ISBN: 978-65-5846-158-6.

https://doi.org/10.7476/9786558461586.0007.

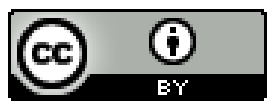

All the contents of this work, except where otherwise noted, is licensed under a $\underline{\text { Creative }}$ Commons Attribution 4.0 International license.

Todo o conteúdo deste trabalho, exceto quando houver ressalva, é publicado sob a licença Creative Commons Atribição 4.0.

Todo el contenido de esta obra, excepto donde se indique lo contrario, está bajo licencia de la licencia Creative Commons Reconocimento 4.0. 


\section{Cidades novas e a necessidade}

Segunda parada: Serra do Navio, Amapá.

Sob o solo brasileiro, reservas e mais reservas minerais repousam à espera de serem subtraídas, processadas e comercializadas. Reservas como a de manganês na Serra do Navio, no estado do Amapá. Em plena selva amazônica, a descoberta, na década de 1940, desse importante minério - indispensável à indústria do aço despertou o interesse do governo e de empresas privadas.

Declarada reserva nacional por decreto-lei de 1946, sua exploração deveria ficar sob a responsabilidade de uma empresa brasileira. Após concorrência pública aberta em 1947, a pequena ICOMI S.A. - Indústria e Comércio de Minérios -, presidida pelo engenheiro Augusto Trajano de Azevedo Antunes, recebeu autorização para pesquisar as jazidas (MONTEIRO, 2003).

Tal sondagem e divulgação do volume de minério encontrado fez valorizar o capital da empresa, ${ }^{1}$ que, em 1950, se associou à gigante norte-americana Bethlehem Steel Company (indústria metalúrgica). Esta, além do aporte financeiro, introduziu a tecnologia indispensável para a extração, como apontou o relatório da ICOMI de 1960:

[...] na ocasião, não existindo no país nem a técnica especializada nem os recursos financeiros que permitissem realizar obra de mérito, à altura dos interesses da Nação, a ICOMI buscou entendimentos no exterior, tendo conseguido interessar a Bethlehem Steel Company, empresa americana, que reunia todas as credenciais

1 À época, o maior produtor de manganês no mundo era a União Soviética, que, em plena Guerra Fria, suspendeu sua exportação e deixou seu maior rival, os Estados Unidos da América, sem a principal matéria-prima para a produção de aço. 
para tornar o empreendimento um sucesso completo. (apud MONTEIRO, 2003, p. 118).

Fosse por jogada política de um governo liberal, fosse um processo natural do mercado, é fato que a presença das minas de manganês na Serra do Navio demandava uma reestruturação ambiental para dar suporte às atividades minero-metalúrgicas, cuja concessão para exploração foi fornecida em 1953 por um período de 50 anos.

Distante cerca de 200 quilômetros da capital Macapá, a primeira necessidade foi ligar a área, localizada no centro do então Território Federal do Amapá, até o rio Amazonas: um corredor que levasse a produção diretamente das jazidas ao porto. Assim, uma linha férrea de 193 quilômetros foi implantada pela ICOMI bem como um bairro portuário no município de Porto Santana, a Vila Amazonas - inicialmente Vila de Macapá. Mas havia ainda a carência de um núcleo urbano de apoio na zona de extração e preparação do minério. Foi assim que surgiu, nos anos 1950, a CN Serra do Navio.

Tanto o projeto da vila portuária quanto o da CN empresarial no meio da floresta ficariam a cargo de um escritório de arquitetura selecionado após convites realizados pela própria ICOMI. A escolha recaiu sobre o ateliê, sediado na capital paulista, do arquiteto-engenheiro Oswaldo Arthur Bratke (1907-1997), pela postura extremamente pragmática dada aos seus projetos (SEGAWA; DOURADO, 1997). O contrato vigorou de 24 de outubro de 1955 a 8 de janeiro de 1960 - data de entrega da obra finalizada.

A “arte de bem projetar e bem construir”, como enfatizam os autores Hugo Segawa e Guilherme Dourado no livro Oswaldo Arthur Bratke, de 1997, refletiu-se nas casas modernistas e nos edifícios públicos que o profissional brilhantemente formalizou em centenas de aquarelas pinceladas desde sua formação, em 1931, na Escola de Engenharia da Universidade Mackenzie (SP). Um arquiteto preocupado não apenas em transformar a cultura e os conceitos de sua época em obras arquitetônicas, mas persuadido em realizar um espaço com qualidade ambiental, de traços elegantes, estruturas delgadas, aberturas milimetricamente posicionadas, 
proporcionando jogos de luz e sombra, materiais ricamente explorados, além do uso indiscriminado de recursos tecnológicos - brises, caxilhos, cobogós etc. - a favor do bem-estar do usuário.

Predicados que o arquiteto, natural de Botucatu (São Paulo), não omitiu nos projetos urbanísticos para a Vila Amazonas e para a CN empresarial Serra do Navio. Em contrato assinado, Bratke foi incumbido pela empresa ICOMI de: planejar o urbanismo de ambos os núcleos com a devida infraestrutura (vias, redes de água, esgoto, águas pluviais, energia etc.); projetar casas conforme a hierarquia funcional (de operários a trabalhadores de alto escalão); projetar edifícios públicos (hospitais, escolas, clubes e demais prédios de interesse coletivo) - tudo devidamente desenhado em plantas, cortes e fachadas e orçado a cada etapa de execução. O programa previsto deveria garantir para Serra do Navio completa independência e autossuficiência (SEGAWA; DOURADO, 1997).

O empenho do arquiteto paulista pode ser verificado pelas frequentes idas ao Amapá a fim de obter conhecimento sobre sua realidade, vivenciando aspectos sociais e monitorando, de perto, o despertar de uma nova cidade. Além disso, viajou também à Venezuela - país com as mesmas condições climático-ambientais -, visando a enriquecer seu repertório. Lá, Bratke visitou cidades empresariais, uma delas a El Pau, projetada pela empresa Bethlehem Steel Company. Porém, os estudos de casos analisados só serviram como contrarresposta, algo que deveria ser evitado no projeto brasileiro. Segundo o arquiteto (apud SEGAWA; DOURADO, 1997), essas cidades eram estruturalmente mal organizadas, com moradias de baixa qualidade para os operários, sendo fonte de interesse apenas pelas informações repassadas por seus habitantes, como o ritmo de vida e as necessidades dos moradores de uma vila empresarial.

Assim, a proposta para Serra do Navio nasceu, contendo uma preocupação ambiental e disposta a oferecer condições mínimas a todos os seus moradores, sem distinção. De início, Bratke estipulou o tamanho real da cidade, com auxílio de funcionários da própria empresa, chegando a uma previsão de 1.729 habitantes para a fase inicial e 2.544 para a fase final - número ampliado, posteriormente, para 
3.500 pessoas (SEGAWA; DOURADO, 1997). Tais dados e prognósticos foram articulados em tabelas, em que o autor planejou, justificou e dimensionou todos os componentes urbanos necessários à $\mathrm{CN}$.

Enquanto todo o projeto era detalhado no ateliê em São Paulo, Bratke, no Amapá, selecionava as tecnologias e os materiais a serem empregados. Cimento, telhas de fibrocimento e 20 tipos de madeiras locais foram meticulosamente articulados na confecção dos edifícios pelo arquiteto modernista, sob a orientação do engenheiro Luiz de Mello Matos, amigo de Augusto Trajano Antunes (ICOMI) e parceiro de Bratke em obra paulista. Os materiais industrializados eram trazidos após longa jornada de estados do sul do país ou de Miami (EUA). As obras eram racionalmente projetadas para garantir uma construção rápida e sem desperdícios. Vidros, por exemplo, foram minimamente utilizados somente em clubes e algumas casas - devido ao clima local e ao custo elevado, sendo substituídos por outras soluções mais apropriadas - telas, mosquiteiros e painéis em madeira com aberturas pivotantes. A funcionalidade e o acabamento das obras arquitetônicas foram condizentes com o plano urbanístico proposto para o novo assentamento.

Localizado a 1,2 quilômetro da área de mineração e distante do rio, devido à neblina matutina, o plano urbano herdou o viés modernista de Bratke. Ao adequar o traçado à geomorfologia do terreno, o arquiteto setorizou as funções urbanas em meio à clareira aberta na floresta (REVISTA AU, 1987). Depois de inúmeros estudos, a CN foi organizada em dois polos interligados por um eixo principal em torno do qual foram dispostos os principais equipamentos urbanos: hotel, centro esportivo, clube, hospital, centro cívico e escola. Cada polo recebeu vias locais e tipos de habitações diferenciadas, sendo um conjunto para operários (o mais adensado, dividido em moradias para famílias e alojamentos para solteiros) e outro para funcionários formados (dividido em moradias para funcionários de nível médio e para graduados). Todo o assentamento foi implantado com uma lacuna de 25 metros de distância da floresta - evitando-se transtornos com a queda de árvo- 
res - e ambientado por uma "flora exótica”, elaborada por um jardineiro alemão indicado pelo professor de Botânica da USP, Aylthon Joly Brandão (SEGAWA; DOURADO, 1997, p. 267).

Aqui, portanto, mais um exemplar da urbanística brasileira merecedor de nossa atenção pela habilidade com que seu plano foi conduzido pelas mãos do arquiteto-engenheiro Oswaldo Arthur Bratke. Interessa-nos, contudo, sua inclusão nesta pesquisa por uma característica em particular: a necessidade de sua criação como apoio às atividades previstas por seus empreendedores.

Figura 8: Serra do Navio

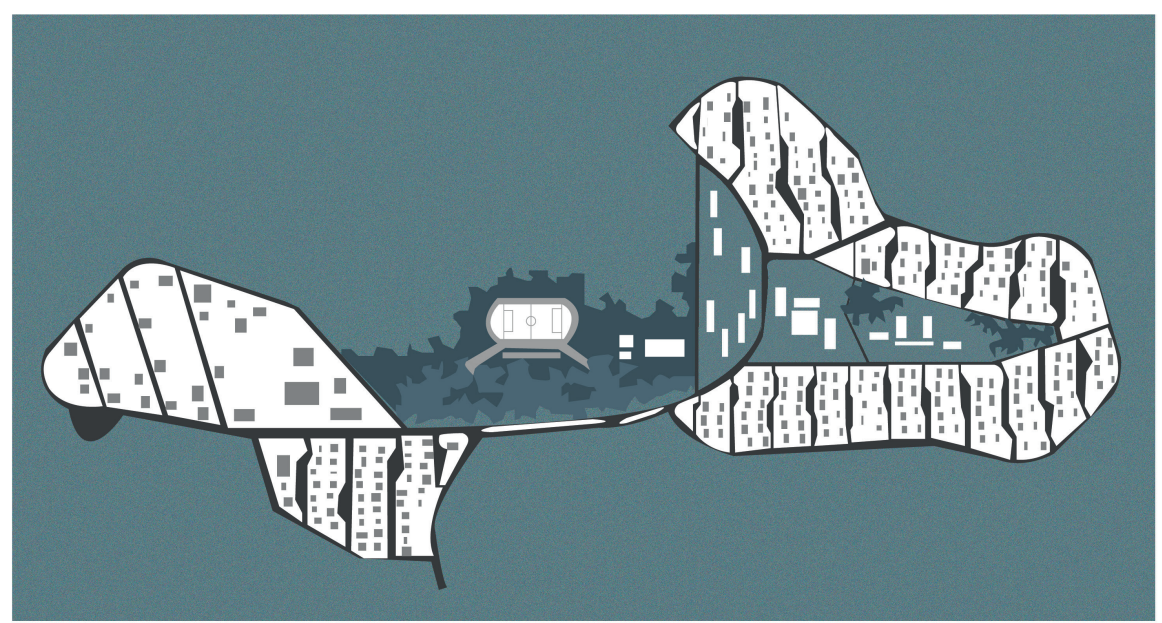

A exploração do minério de manganês em região inóspita seria, evidentemente, inviável sem a presença da CN. A oferta de trabalho e a demanda por mão de obra qualificada para tal produção dependiam diretamente da construção de espaços estáveis. Urgia, portanto, um ambiente artificialmente planejado e rapidamente executado para atender às exigências de seus investidores e de seus moradores. Nesse sentido, a CN surgiu como uma necessidade, com a função principal de acolher trabalhadores e dar suporte às atividades extrativistas. 
O caso de Serra do Navio não foi o primeiro e nem o último de nossa história. As CNs empresariais de Fordlândia (1920) no Pará, Monlevade (1934) em Minas Gerais, e Votorantim (1940) em São Paulo atestam tal antecedência. Assim como políticas desenvolvimentistas adotadas, principalmente durante o regime militar (1964-1985), vão sequenciar o nascimento de outras CNs similares.

Em 1972, por exemplo, o governo do presidente general Emílio Garrastazu Médici (1905-1985) lançou o I Plano Nacional de Desenvolvimento (1972-1974), cuja responsabilidade de implementação foi dada ao Serviço Federal de Habitação e Urbanismo (Serfhau). ${ }^{2}$ Os objetivos do I PND incluíam: propor um crescimento econômico para o país mediante um processo de competição conjunto com um processo de integração de áreas defasadas; compatibilizar os planos setoriais territorialmente, visando à formação rápida de uma estrutura nacional eficiente e adequada de produção, distribuição e consumo de bens e serviços; e colocar o país como potência mundial (BRASIL, 1972).

Para elevar o Brasil a uma categoria de país desenvolvido, destacam-se aqui as seguintes atividades previstas (BRASIL, 1972):

1. implantação de novos instrumentos para modernizar a empresa nacional;

2. atuação eficiente do governo;

3. mobilização mais intensa do sistema financeiro nacional e do mercado de capitais;

4. implementação da Política Tecnológica Nacional;

5. efetivação de certo número de grandes programas de investimentos, como os programas de expansão da Siderurgia e Petroquímica;

2 O Serviço Federal de Habitação e Urbanismo (Serfhau) foi o órgão nacional de desenvolvimento urbano responsável pelos projetos e planos na primeira fase de planejamento do regime militar (1964-1974). Ligado ao Ministério do Interior (Minter), foi criado juntamente com o Banco Nacional da Habitação (BNH) pela Lei n. 4.380, de 21 de agosto de 1964, posteriormente regulamentada pelo Decreto n. 59.917, de 30 de dezembro de 1966. 
6. política de aproveitamento dos recursos humanos do país como fator de produção e de consumo; e

7. realização de estratégia regional para efetivar a integração nacional.

Esse é um panorama que nos permite compreender as conjunturas do surgimento de CNs empresariais, principalmente ligadas a um ambicioso programa de pesquisa e aproveitamento de recursos minerais.

Mediante sondagens realizadas por órgãos ligados ao governo (como as Superintendências de Desenvolvimento - Sudam, Sudene e Sudeco - e o Instituto Nacional de Colonização e Reforma Agrária - Incra), reservas de bauxita, cobre, manganês etc. foram identificadas e repassadas por concessões temporárias a empresas estatais, responsáveis por explorá-las e exportar seus produtos. Desse modo, polos siderúrgicos surgiram em diferentes unidades federativas, dando origem a CNs, como Carajás (1973) no Pará, Camaçari (1977)³ e Caraíba (1978) na Bahia, e Primavera (1979) em São Paulo. CNs cujo DNA apresenta os seis segmentos apontados: o envolvimento de empreendedores (governo), um sítio estratégico (acima de jazidas minerais), a participação de profissionais (arquitetos e engenheiros) em seus projetos, um tempo preciso de construção e fundação e, principalmente, a necessidade de existirem. O segundo segmento de estruturação do DNA das CNs, a necessidade, possibilita-nos responder por que tais assentamentos foram criados, assim como identificar a função dominante presente ao menos em sua fase inicial.

\subsection{Funções e exemplares}

Toda cidade, espontânea ou criada, tem por função conceitual "transformar o poder em forma, a energia em cultura, a matéria morta em símbolo vivo de arte, a

3 A CN de Camaçari, a 46 quilômetros de Salvador, nasceu em 1977, quando o plano urbanístico, confiado à prefeitura do município, foi iniciado. Até essa data, não passava de uma pequena cidade de menos de 20 mil habitantes, sendo escolhida para receber o segundo complexo petroquímico do país (D’ARC; SCHNEIER, 1983). 
reprodução biológica em criatividade social” (MUMFORD, 1992, p. 30, tradução nossa). ${ }^{4}$ No cotidiano da vida urbana, toda cidade deve apresentar funções práticas, aquelas relacionadas às necessidades de seus habitantes.

O sobressalto de uma dessas funções frente às demais pode servir para caracterizar uma cidade, como fez o historiador Pierre Deffontaines ao qualificar os núcleos do período colonial brasileiro. Segundo o autor, as antigas aldeias, vilas e cidades podiam ser classificadas pelas atividades principais que abrigavam: "reduções missionárias”; “aglomerações de origem militar”; “cidades mineiras”; "pousos nas estradas” (cidade de viajantes); “cidades de navegação fluvial ou marítima”; "vilas de domingo”; e “aldeias indígenas” - uma distinção social (apud FRIDMAN, 2005, p. 46-48).

Não exclusivo a historiadores, tal método taxonômico transitou por outras disciplinas, como na geografia, onde encontramos as cidades do café, da borracha, da indústria, das colônias de imigrantes, de comércio, balneárias e turísticas (SOUZA, 2001). No Direito Urbanístico, em rastreamento realizado por Nuñez Ruiz, outra possibilidade nos é repassada pela cidade:

[...] militar (cidade-quartel, bases e centros de instrução, aeroporto

e base naval militar); política (cidade-internacional, cidade-nação, cidade regional ou capital); religiosa (cidade de peregrinação, cidade de festas religiosas); intelectual (cidade universitária, cidade estudantil, cidade patrimônio, cidade cultural); econômica (cidade boca ou sertão, cidade ponte de trilhos, cidade agrícola, cidade comercial, cidade financeira, cidade industrial, cidade centro de serviços); turística e/ou residencial (cidade dormitório); médico-sanitária (balneárias etc.); recreativa (beira-mar, montanha). (apud BRASIL, 1973, s.p.).

4 “[...] trasformare il potere in forma, l'energia in cultura, la materia morta in simbolo vivente dell'arte, la riproduzione biologica nella creatività sociale." 
Essa amostra de enquadramentos funcionais cabe tanto às cidades tradicionais como às CNs, com uma singela diferença: enquanto, numa cidade tradicional, tal qualificação é feita após seu desenvolvimento, quando já adquiriu sua identidade, numa CN a função prevalecente é determinada no momento de sua concepção, com o auxílio de seu empreendedor, mesmo antes de sua materialização. Não importa se, ao longo de sua história, outras funções venham a se sobrepor à sua função original - a CN sempre terá, em sua certidão de nascimento, a causa para qual foi gerada.

Nesse sentido, da facilidade em identificar a função para qual uma cidade foi criada, muitos autores tiram partido para classificar as CNs. ${ }^{5}$ Tal apropriação é endossada por uma rápida análise urbana, na qual alguns elementos particulares da paisagem podem revelar sua função de berço, seja pela presença da igreja na praça matriz, de um centro cívico, de um forte, de uma ferrovia, de uma rodovia, de uma hidrelétrica, de uma rede hoteleira, de uma empresa mineradora etc.

Assim, em grande parte dos estudos analisados, ${ }^{6}$ a taxonomia desse tipo urbanístico é realizada pela função para a qual tal núcleo foi empreendido: CN administrativa, $\mathrm{CN}$ de colonização, $\mathrm{CN}$ ferroviária, $\mathrm{CN}$ de realocação, $\mathrm{CN}$ balneária, CN satélite, CN de expansão, entre outras.

Para R. C. Gupta (1983), as CNs foram construídas para propósitos especiais, seja sediar: um porto (CN de Tema em Gana, CN de Kompong Som no Camboja, e CNs de Kandala e Maldia na Índia), uma indústria (as steel cities na Índia), uma capital (Chandigarh, Islamabad, Brasília), uma nova zona agrícola (CNs da região do Mandi, em Punjabi), uma expansão urbana (new towns inglesas ou

5 Embora não identificado na literatura analisada, reconheço que outras possibilidades de classificação seriam cabíveis, como separar CNs pela filiação projetual adotada, pelo período no qual foi implantado, pelo tipo de sítio escolhido, pelos profissionais envolvidos etc.

${ }^{6}$ Referenciam-se aqui, por exemplo, os trabalhos: Les villes nouvelles, de Pierre Merlin (1969a); La création des villes nouvelles, de Vito Ahtik (1969); El proceso de urbanización en America Latina y Venezuela, de Samuel Benchimol (1973); New-town planning, de Gideon Golany (1976); New towns, de Frederic Osborn e Arnold Whittick (1977); Cidade brasileira, de Murillo Marx (1980); Arquitetura contemporânea no Brasil, de Yves Bruand (1981); New towns around the world, de Stephen Potter (1987); Les villes dans le monde, de Pierre Bloc-Duraffour (1998); e A cidade como história, de Eloísa Pinheiro e Marco Aurélio Gomes (2005). 
CN Diego de Losada, na Venezuela). Sequenciando, Farhad Atash (2000, p. 68, tradução nossa) ${ }^{7}$ acrescenta:

Cidade nova como instrumento de abertura de novas regiões a serem exploradas, como a Ciudad Guayana (Venezuela); cidade nova utilizada para promover desenvolvimento em áreas remotas, menos desenvolvidas, pela concentração populacional, e de atividades econômicas em áreas que possuíam grande potencial.

Já um estudo iraniano (IRAN, 1991) limitou as CNs a apenas três tipos:

1. Cidades residenciais (cidades-dormitórios), como as cidades novas criadas ao redor do Cairo, Caracas, Hong-Kong, Shangai, Paris e Londres;

2. Cidades-satélites, como Tema em Gana, San Pedro na Costa do Marfim e Fulad Shahr no Irã; e

3. Novas cidades no estrito senso da palavra, como as cidades administrativas e centros políticos de Chandigarh (Índia), Brasília (Brasil), Abuja (Nigéria), Duduma (Tanzânia).

Focando nossas atenções no contexto nacional, em minha trajetória de pesquisa, cheguei às seguintes possibilidades: 1) CN empresarial (Barcarena, no Pará, Alumínio, em São Paulo, ou Siderópolis, em Santa Catarina); 2) CN ferroviária ou "boca de sertão” (Erechim, no Rio Grande do Sul, Franca e Jales, em São Paulo); 3) CN rodoviária (Marabá, no Pará, e Ceres, em Goiás); 4) CN de penetração (Aragarças, em Goiás); 5) CN de realocação (Remanso, na Bahia, Canindé do São Francisco, em Sergipe, ou Aripuanã, em Mato Grosso); 6) CN administrativa (Oeiras, no Piauí, Aracajú, em Sergipe, e Palmas, no Tocantins);

7 "New town as an instrument for opening new regions to be explored, such as Ciudad Guayana (Venezuela); a new town used to promote development in remote, less developed areas, by population concentration and economic activities in areas that possessed great potential." 
7) CN balneária ou recreativa (Lambari, em Minas Gerais, ou Águas de Lindóia, em São Paulo); 8) CN de colonização ou fronteiriça (Panorama, em São Paulo, Ângulo, no Paraná, ou Nova Veneza, em Goiás); 9) CN religiosa (missões do Rio Grande do Sul); 10) CN de defesa (São Luís, no Maranhão, e Nossa Senhora da Conceição, em Rondônia); 11) CN satélite (Taguatinga, Guará I e Guará II, no Distrito Federal); e 12) CN de expansão (Santos, em São Paulo, e Boa Vista, em Roraima). Uma lista efêmera, aberta a acréscimos e sugestões!

No conjunto, podemos verificar aspectos comuns em todas as classificações. As funções das CNs são determinadas em sua origem por seus empreendedores, visando a atender necessidades de cunho político, econômico, social e/ou cultural. Isso se torna claro nas produções realizadas em diversos países.

Se, na Antiguidade, no Medievo e na Modernidade, a recorrência a CNs se dava pela preocupação em defender fronteiras (acampamentos romanos) e ocupar territórios (cidades da América espanhola e portuguesa), no mundo contemporâneo ela será aplicada conforme as necessidades de nossa Era. Uma diversidade de funções que percorrem desde as emblemáticas CNs capitais, se popularizam com as CNs satélites (new towns, villes nouvelles etc.), repousam sobre balneários luxuosos no litoral, no campo ou nas montanhas, prosseguem com sua luta por ocupar e colonizar territórios pouco explorados e personificam a alma econômica pós-Revolução Industrial mediante CNs empresariais.

Mais emblemáticas e simbólicas do que numerosas, as CNs administrativas apresentam uma função que justifica sua existência: concentrar as estâncias governamentais do poder público. Por razões estratégicas de uma política frequentemente associada às necessidades econômicas e de planejamento territorial, numerosos governos adotaram as CNs administrativas como saída. Uma solução que Pierre Merlin (1977) também interpretou como uma tentativa de romper a dominação de uma ou mais grandes cidades situadas numa região muito desenvolvida (Sidney e Melbourne, na Austrália; e Rio de Janeiro e São Paulo, no Brasil), ou uma vontade de ocupar todo um espaço nacional, centralizando a posição de 
sua capital (Brasília e Ankara), ou ainda uma devolução de uma capital a um Estado repartido (Chandigarh).

Sejam quais forem os propósitos originais, governos dos EUA, Austrália, Turquia, Índia, Brasil, Nigéria, Cazaquistão etc., além de comandos regionais, decidiram por transferir todo o aparato administrativo de capitais anciãs para um espaço urbano inédito, especificamente projetado para atender às exigências de uma sede governamental. Mesmo na França, onde já houve uma mudança planejada de capital no século XVII (Versalhes), a ideia de retirar a sede administrativa de Paris voltou à tona em 1960 (VOLDMAN, 1990). Naquele ano, a revista Architecture d'Aujourd'hui lançou um grande projeto visando à construção de uma "Paris Paralela”, uma nova capital para abrigar poderes executivo, legislativo e judiciário franceses. Uma espécie de cidade-satélite com função administrativa, cujo objetivo era desafogar a adensada região parisiense.

Ou seja, uma possibilidade de expansão urbana controlada: um artifício utilizado pelo governo Vargas nos anos 1930 e 1940 para descongestionar a capital paulista; uma reabilitação pós-guerra, regularizada e batizada na Inglaterra como new towns em 1946; um tipo disseminado por outros países mediante dezenas de cidades-satélites - inclusive na França, que não teve a "Paris paralela”, mas, sim, as villes nouvelles. Independentemente da indumentária vestida, as CNs satélites (denominação adotada pelo presente autor) foram uma alternativa face à urbanização periférica e espontânea - “meio clássico de extensão das cidades” (ALLART, s.d., p. 12, tradução nossa) ${ }^{8}$ - ou uma resposta aos grandes conjuntos habitacionais - "guetos sem almas, longe de tudo e, sobretudo, de empregos" (GUYARD, 1980, p. 25, tradução nossa). ${ }^{9}$

Ao criar uma CN satélite, a preocupação primordial é evitar que ela se torne uma cidade-dormitório, dependente da “cidade-mãe”. Para isso, planeja-se em seu domínio um equilíbrio básico entre oferta de moradias e oferta de empregos 8 “[...] moyen classique d'extension des villes [...]"

9 “[...] ghettos sans âme, loin de tout et surtout des emplois [...]” 
(indústria, comércio e serviço). Vejam-se as cidades-satélites na Suécia (1950-1954), chamadas Cidades ABC (traduzido por Casa, Trabalho e Serviços). Nelas, técnicos de planejamento urbano utilizaram a seguinte fórmula:

A CN satélite deveria ter uma comunidade balanceada entre 80 mil e 100 mil habitantes, com densidade de 30 a 80 pessoas por acre, aumentando conforme a proximidade do centro comercial. Haveria uma hierarquização de centros: centro comercial principal, centro administrativo próximo à ferrovia, centro de vizinhança com escola. As habitações foram divididas em $60 \%$ coletivas (edifícios em barra) e individuais (casas isoladas); e as vias adotaram o sistema norte-americano de separação entre vias de pedestres e de veículos. (CERVEO, 1995, p. 44, tradução nossa). ${ }^{10}$

10 "The satellite towns should have a balanced community between 80,000 and 100,000 inhabitants, with density of 30 to 80 people per acre, increasing as the proximity of the mall. There would be a hierarchy of centers: main shopping center, administrative center next to the railway, neighborhood center with school. The dwellings were divided in 60\% collective (buildings in bar) and individual (isolated houses); and the roads adopted the American system of separation between pedestrians and vehicles." 
Cidades novas

Figura 9: Paris paralela

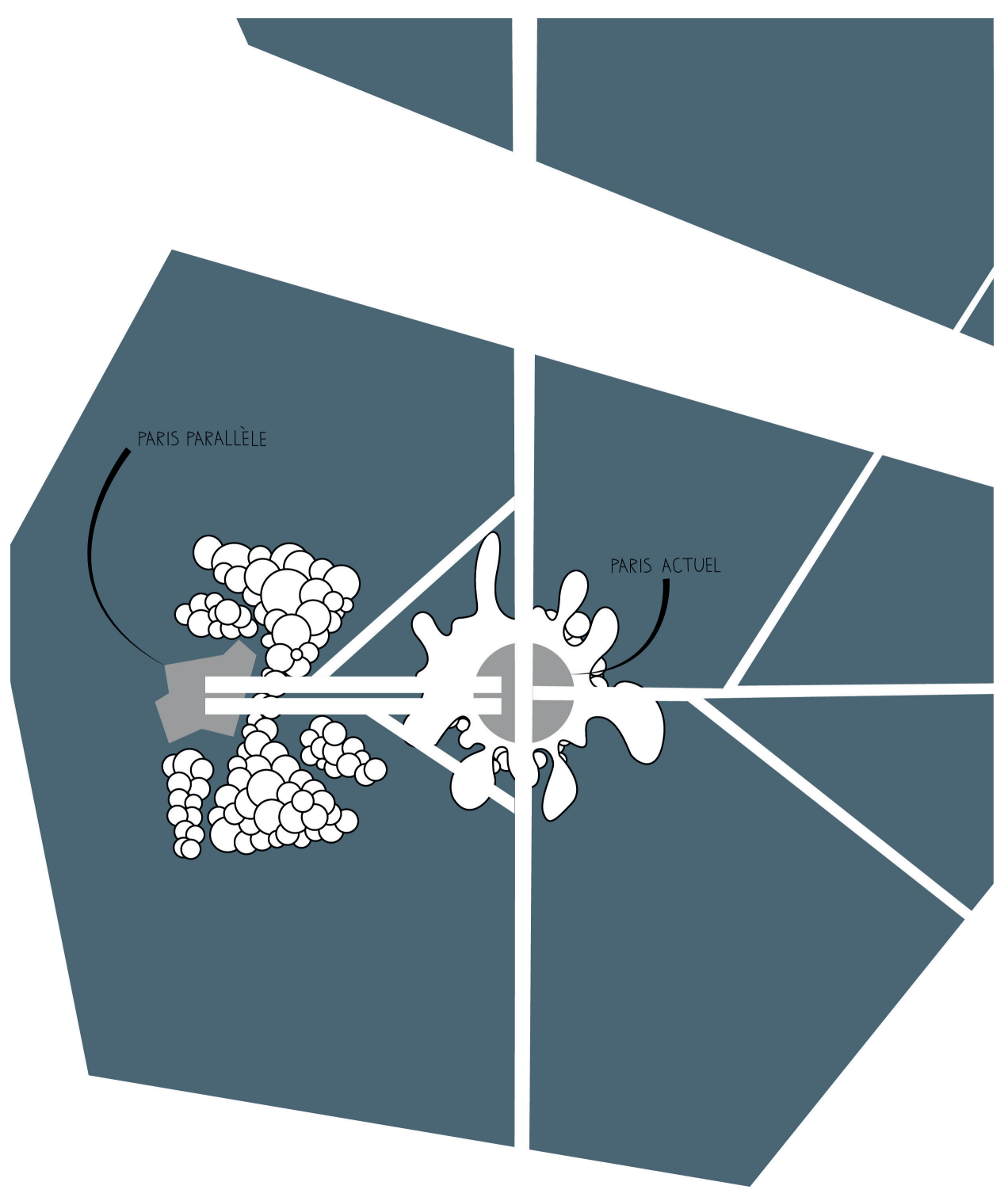


Equilíbrio igualmente imaginado para as villes nouvelles francesas, planejadas para: acalmar as lutas sociais que reivindicavam moradias melhores que la sarcellite (cinturão de conjuntos habitacionais da periferia parisiense); dotar a economia francesa de uma indústria de escala internacional via planejamento territorial; controlar o desenvolvimento urbano na medida do possível, canalizando o desenvolvimento da capital e sua "mancha de óleo"; e promover o equilíbrio emprego-trabalho a fim de reduzir as migrações cotidianas e de melhorar a qualidade de vida de seus habitantes (PAQUOT; PAQUOT, 1977).

Segundo Stéphanie Vermeersch (2005), mais que apenas um equilíbrio entre emprego e moradia, as villes nouvelles deveriam oferecer empregos de alto padrão e qualidade espacial para seus novos habitantes, tornando-se um modelo ideal de vida. Assim, para cada CN proposta, uma vocação particular foi atribuída: Évry seria um centro urbano atrativo; Marne-la-Vallée deveria reestruturar o Grande Leste; Cergy-Pontoise viraria um prolongamento terciário de La Défense; Saint-Quentin-en-Yvelines adequaria o desenvolvimento urbano em curso segundo uma qualidade urbana a oferecer; e Melun-Sénart privilegiaria ser uma cidade verde (BEHAR; ESTEBE; GONARD, 2002).

Dessa forma, as CNs satélites, além da conhecida função de responder ao desenvolvimento das grandes cidades, oferecendo moradia, abrigando indústrias, comércios e infraestrutura adequada, adquiriram a responsabilidade de ser um centro com identidade própria. Ideal que se buscou seguir no Egito, na Escócia, na Tailândia e nos EUA.

No Egito, o processo de controlar o crescimento da capital Cairo data do início do século XX, com as primeiras cidades-satélites, Heliopolis e Maadi (TOULAN, 1979-1980), que se aproximam mais de subúrbios-jardins que de cidades. Posteriormente, vieram: Madinet El Awkaf (1940) e Madinet Nasr (1960). Em 1968, o Plano Regional de Desenvolvimento para o Grande Cairo previa a implantação de quatro novas cidades para abrigar 250 mil pessoas até 1990. O plano efetiva- 
mente foi iniciado apenas em 1975, e tinha por objetivos: redistribuir população e atividades econômicas, proteger terras agrícolas ao longo do rio Nilo, criar novas oportunidades de emprego e melhorar a condição de vida (EGYPT, 1996).

Na Escócia, o período de 1947 a 1966 foi marcado pelo surgimento de cinco CNs: East Kilbride (1947), Glenrothes (1948), Cumbernauld (1955), Livingston (1962) e Irvine (1966). A intenção inicial para a criação desses novos centros foi dispersar a população e as indústrias de áreas urbanas congestionadas, como Glasgow. Posteriormente, somou-se a esse objetivo a função econômica. Esperava-se que essas CNs satélites servissem como áreas de expansão econômica e de desenvolvimento industrial (LLOYD, 1989).

Num dos tigres asiáticos, a política de implantação de CNs para domar o espraiamento das grandes cidades, como a capital Bancoc, foi iniciada em 1963, com uma lei sobre planificação, composta de 64 artigos. Porém, somente em 1970, com o Plano Litchfield, houve uma regulamentação para a criação de CNs. O empreendimento ficaria a cargo de empresas privadas tailandesas - que estabeleciam, regularmente, parcerias com empresas norte-americanas -, encorajadas por empréstimos públicos e isenção de impostos (BARON, 1992). Dentre os objetivos da criação das cidades estavam: reduzir o déficit de moradia; reduzir a taxa de crescimento demográfico; reduzir o tráfego urbano; maximizar a utilização do solo na zona de projeto; criar oportunidades de emprego; diminuir a pressão sobre as infraestruturas da cidade-mãe; e proteger o meio ambiente. Na Tailândia, as CNs satélites deveriam abrigar comércio, indústrias, escolas, moradias, espaços verdes, etc., devendo depender da cidade-polo (localizada numa faixa entre 30 e 80 quilômetros de distância) apenas para certas atividades especiais.

Já nos Estados Unidos da América, a construção de CNs satélites foi uma técnica para canalizar o crescimento urbano e o desenvolvimento da economia (UNITED STATES OF AMERICA, 1981). Essa técnica deveria frear a expansão urbana das grandes cidades e oferecer habitação e emprego de modo igualitário: uma suposição que, na realidade, viu as CNs satélites - como Reston e Columbia, 
próximas a Washington D.C.; Foster City e Redwood Shores em São Francisco; Valencia e Irvine em Los Angeles - receberem, a partir dos anos 1960, apenas uma pequena fração do crescimento populacional (TURNER; SMULIAN, 1974). Ou seja, passos em falso constatados por Frank G. Mittelbach (1973), para o qual a alta expectativa de que cidades novas controlariam e redirecionariam o crescimento de grandes cidades nunca ocorreu. Parafraseando o autor, essas cidades novas tiveram sim é que resolver os problemas sociais que nelas apareceram, além da absorção de grandes investimentos para seu planejamento.

Independentemente do resultado obtido, a CN como controle da expansão urbana apresenta semelhanças à outra, a CN de ocupação territorial (colonização ou fronteiriças). A ordenação da ocupação do espaço pela implantação de cidades, seja nas cercanias de uma grande cidade, seja em regiões áridas, foi um dos campos férteis desse tipo urbanístico. Ao inseminar artificialmente uma rede de núcleos urbanos, busca-se: controlar a imigração interna de um país; colonizar áreas ermas, proteger e defender fronteiras; ${ }^{11}$ desenvolver regiões pouco industrializadas; e abrir novas franjas agrícolas, como na Malásia, onde o governo local construiu, entre os anos 1970 e 1980, assentamentos para urbanização da população rural, modernização e desenvolvimento agrário, diminuindo disparidades entre regiões e grupos étnicos (SALLEH; CHOGUILL, 1992). São políticas adotadas principalmente em países em via de desenvolvimento e ocupação (SAFIER, 1977), onde as CNs são e foram projetos concebidos para responder às necessidades criadas por programas de desenvolvimento regional ou nacional.

Foi assim com as CNs norte-americanas do século XIX, junto à costa oeste. Embora iniciativas privadas, as cidades de ocupação foram planejadas não apenas para servir às necessidades próprias, como também para compor uma rede de assentamentos urbanos de fronteira e incentivar a economia daquela região (HAMER, 1994). Foi assim na Austrália do pós-Primeira Guerra Mundial, quando os soldados de retorno

\footnotetext{
${ }^{11}$ As bastides francesas, além da função de defesa, surgiram para controlar, consolidar e desenvolver os domínios de um determinado poder (real, senhorial, eclesiástico), assim como fixar população em zonas desabitadas, desenvolvendo agricultura e comércio na região (PANERAI et al., 1985).
} 
ao país foram assentados em CNs criadas em áreas pouco adensadas (RUSHMAN, 1976). Foi assim na URSS e suas centenas de navyé goroda. Foi assim no Brasil de Vargas e sua "Marcha para o Oeste”, de Juscelino Kubitschek e sua Brasília, do Regime Militar e sua política de desenvolvimentismo e integração nacional. Foi assim em países de menor abrangência territorial, como Israel e Senegal.

Desde a origem do Estado israelense, em 14 de maio de 1948, o poder local estabeleceu uma política de implantação de CNs como modo de demarcar os limites e demonstrar a posse sobre o seu território. Entre 1948 e 1963, mais de 30 CNs de colonização foram estabelecidas no país, servindo para abrigar imigrantes judeus vindos de todas as partes do planeta - uma distribuição populacional não apenas em zonas agrícolas (EFRAT, 1994). Dessa experiência, nasceram, num prazo de 15 anos, Qiryat Shemona, Afula, Qiryat Gat, Beer Sheva, Ashdod, Elat, Arad e Karmiel.

No Senegal, por sua vez, as CNs de ocupação territorial surgiram inseridas numa política de reforma fundiária, visando ao desenvolvimento geral do país. Para solucionar os problemas fundiários, três níveis de intervenção foram propostos: 1) uma intervenção na zona rural; 2) uma ação organizada ao nível de cidades-periódicas e de cidades novas criadas ex nihilo; e 3) uma política coerente no eixo Dakar-Thiès (WADE, 1973).

Foram CNs de ocupação, colonização e fronteiriças (planejamento territorial) que ficaram, em vários momentos, associadas a outras funções, como a de subsidiar atividades de exploração industrial (função econômica). ${ }^{12}$ Com isso, conseguiu-se, em uma única empreitada, urbanizar e industrializar uma região pouco ocupada ou predominantemente agrícola - fato ocorrido na Índia, Venezuela, Polônia, Hungria, Gana, Gabão e no Canadá, onde a exploração de recursos florestais e minerais, na província de Alberta, durante o século passado, atraiu um grande contingente populacional (BAILLY, 1972).

\footnotetext{
12 Além da exploração mineral, as funções de expansão e ocupação territorial estão interligadas a ações bem definidas, como implantação de ferrovias e rodovias, construção de fortificações, criação de novas zonas agrícolas etc.
} 
Com a vontade de descentralizar a economia - situada, sobretudo, em três grandes cidades: Calcutá, Madras e Mumbai -, o governo indiano propôs quatro CNs empresariais, que nasceram com a função de produção do aço: Rourkela (em Orissa), Bhilai (em Madhya Pradesh), Durgapur (no West Bengal) e Bokaro (em Bihar). Todas planejadas com autonomia em relação a outras cidades, possuindo equipamentos e serviços que pudessem atender à população (KAMBO, 1971).

Na Venezuela, duas CNs empresariais foram estrategicamente propostas: Ciudad Guayana (1960) e El Tablazo (1966). A primeira, localizada no sudeste do país (500 quilômetros de Caracas), tinha por obrigação fixar o marco urbano de crescimento de áreas que continham riqueza natural. Empreendida pela estatal Corporación Venezolana de Guayana, essa CN foi base para o estabelecimento de uma indústria siderúrgica (fundada em 1962) de projeção nacional e internacional. Já El Tablazo, localizada na parte ocidental do país, próxima à cidade de Maracaíbo, deveria criar infraestrutura necessária para o desenvolvimento de um complexo petroquímico, resolvendo, dessa maneira, problemas de emprego na região (BENCHIMOL, 1973).

Inserida na política econômica do governo da URSS, a CN Nowe Tychy (1951), na Polônia, foi implantada próxima à capital Cracóvia, às margens da região industrial do Alto-Silésio, sobre uma pequena vila existente de 13 mil habitantes - sua população prevista seria de 100 mil habitantes (MALISZ, 1961). Já na Hungria, um plano meticuloso de industrialização do país foi colocado em prática. Dividido em dois períodos distintos, ${ }^{13}$ apresentavam três tipos de CNs empresariais: aquelas próximas a minas; aquelas direcionadas a trabalhos metalúrgicos; e, por último, aquelas relacionadas a empresas químicas (HUNGARY, 1984).

Em países africanos, como Gana e Gabão, as CNs empresariais eram tidas como positivas, pois possibilitavam, ao mesmo tempo, atrair atividades econômicas para um ambiente planejado e, com isso, uma produção eficiente. Contudo, sabemos que

${ }^{13}$ O primeiro período (1945-1960) se atrela ao antigo e rígido mecanismo econômico, quando o Estado forneceu de $55 \%$ a $80 \%$ de suporte financeiro para o desenvolvimento estrutural das CNs. O segundo período (1960-1980) cobriu os anos de novos mecanismos econômicos, quando diminuiu o apoio estatal para $36 \%$, ficando o restante sob a responsabilidade de fontes locais. 
tais empreendimentos, realizados por empresas estrangeiras, eram casos isolados, pouco interativos com a realidade local e quase sempre visavam ao beneficiamento de poucos - em Gana, a CN Bibiani explorava minas de ouro e a CN Akosombo extraía recursos naturais para produção de energia (GHANA, 1973). No Gabão, Gamba foi criada pelo grupo Shell para apoiar a obtenção de petróleo da reserva, descoberto em 1956, na região de Port-Gentil - segunda cidade em população do Gabão. Seu plano, de 1967, foi caracterizado pelo tratamento diferenciado da habitação operária em relação a zonas de uso administrativo. Além disso, sua linha de equipamentos ficou aquém do esperado para o desenvolvimento independente e natural de um novo centro urbano (FRANCE, 1970a).

Além desses casos mais recorrentes - CNs administrativas, cidades-satélites, de expansão territorial, empresariais e balneárias (vistas no capítulo anterior) -, outros casos inusitados surgem a partir de funções específicas. É o caso das sauvetés (cidades-rua) na França e Espanha: CNs criadas ao longo do caminho de Santiago de Compostela para garantir abrigo aos peregrinos, segurança aos seus moradores, além de subsídios econômicos para produções agrícolas locais (PANERAI et al., 1985).

Há exemplos de CNs voltadas ao incentivo à educação, como: na França e sua ville nouvelle universitária de Villeneuve d’Ascq (1966), próxima a Lille (uma das nove CNs do período de Gaulle); na Bélgica e sua Louvain-la-Neuve (1968), uma iniciativa privada para receber a sede da Universidade Católica (alunos, pesquisadores, professores, técnicos etc.) e uma população extra de 50 mil habitantes; e no Japão e seu centro universitário de Tsukuda (2000) (BAUDELLE, 2004b).

CNs criadas após catástrofes naturais, como Agadir, no Marrocos, reconstruída após o terremoto de 29 de fevereiro de 1960, quando 70\% de seus bens materiais foram destruídos, conforme relato de Mahamed Ben Attou (BOUMAZA et al., 2006), e New Nsutam, em Gana, reconstruída em novo sítio após desastre ambiental, são CNs criadas em decorrência de conflitos humanos, como os campos de refugiados africanos, abordados nos estudos de Michel Agier sobre o tema (2001). CNs 
criadas como isolamento de pessoas enfermas, como o leprosário Santo Ângelo em Mogi das Cruzes, no estado de São Paulo.

Chamado de “Asylo Colônia Santo Ângelo”, a cidadela foi projetada em 1918 pelo arquiteto Adelardo Soares Caiuby e inaugurada em 1928. Tinha seu parcelamento dividido em “zona sã e zona doente”, contendo, entre essas, uma "zona intermediária”. A primeira era destinada ao pessoal técnico e administrativo sadio, onde se encontravam a portaria, o almoxarifado, a garagem, a administração e demais serviços. A “zona intermediária” abrigava o pavilhão de economia geral, o posto de fiscalização de visitas e o parlatório. A zona doente abrigava o asilo propriamente dito e ali estavam instalados: o hospital, o pavilhão de clínicas, os dormitórios coletivos, as casas para doentes casados, a cadeia, o cassino, a igreja e a parte esportiva. Esses asilos foram projetados visando à autossuficiência, com uma grande área reservada para atividades agropecuárias, destinadas a prover grande parte do consumo alimentar necessário, e ainda dotados de pequenas fábricas e oficinas (FELICIANO, 2008).

Enfim, um leque de possibilidades que revela a versatilidade de como as CNs foram aplicadas. Uma multiplicidade de funções que, juntamente com o desejo de seu(s) empreendedor(es), articularam a causa de origem das CNs. Um dueto que, ao acréscimo do sítio escolhido, se tornou a trilogia de base, a cadeia preliminar que compõe o DNA das CNs. 